\title{
The Impact of Bank Indonesia Regulation No. 17/3/2015 on Exchange Rate: Analysis Using Vector Error Correction Model (VECM)
}

\author{
Muhamad Yudi Setiawan ${ }^{1 *}$; Tanti Novianti²; Mukhamad Najib ${ }^{3}$ \\ ${ }^{1}$ IPB School of Business, IPB University \\ Jln. Raya Pajajaran, Bogor, West Java, Indonesia 16151 \\ ${ }^{2}$ Department of Economics, Faculty of Economics and Management, IPB University \\ Jln. Agatis, IPB Dramaga Campus, Bogor, West Java, Indonesia 16680 \\ ${ }^{3}$ Department of Management, Faculty of Economics and Management, IPB University \\ Jln. Agatis, IPB Dramaga Campus, Bogor, West Java, Indonesia 16680 \\ 'oudhi77@gmail.com; ${ }^{2}$ tantinovianti@yahoo.com;33najib23@yahoo.com
}

Received: $12^{\text {th }}$ July 2020/ Revised: 24 $4^{\text {th }}$ November 2020/ Accepted: $3^{\text {rd }}$ February 2021

\begin{abstract}
How to Cite: Setiawan, M. Y., Novianti, T., \& Najib, M. (2021). The Impact of Bank Indonesia Regulation No. 17/3/2015 on Exchange Rate: Analysis Using Vector Error Correction Model (VECM). Binus Business Review, 12(2), 131-141.

https://doi.org/10.21512/bbr.v12i2.6570
\end{abstract}

\begin{abstract}
The weakening of the Rupiah against the US dollar has encouraged Bank Indonesia to issued Bank Indonesia Regulation (Peraturan Bank Indonesia - PBI) No. 17/3/2015. The research aimed to analyze the factors that affected the Rupiah exchange rate, the effect of PBI No. 17/3/2015 on the movement of the Rupiah exchange rate, and the behavior of exchange rate movement to the shocks on the variables that influenced it. The research applied secondary data, namely monthly data from January 2008 to April 2019 taken from reliable sources such as National Development Planning Agency (Bappenas), Bank Indonesia (BI), and Statistics Indonesia (BPS). It was explanatory research with a quantitative approach. The studied data were processed with the Vector Error Correction Model (VECM) method to identify long and short-term effects. The results of the long-term equation show that export-import has a negative effect on the exchange rate. Similarly, inflation has no significant effect on the exchange rate. Then, the money supply has a significantly negative effect on the exchange rate. However, the interest rate of Bank Indonesia positively affects the exchange rate. Next, the implementation of PBI No. $17 / 3 / 2015$ has a significant and positive impact on the exchange rate. Last, the crisis condition does not affect the changes in exchange rates.
\end{abstract}

Keywords: Bank Indonesia Regulation, exchange rate, Vector Error Correction Model (VECM)

\section{INTRODUCTION}

The role of the exchange rate is critical to a country. Economic globalization has directed the economic system development to an open economy. The rapid growth of the international economy can accelerate changes in the macro indicators of a country. This development leads to international trade. There are various currencies used to conduct transactions in international trade. The currency difference is a macroeconomic indicator. Therefore, it is necessary to have the same currency unit so that the currencies of both countries can convert into another currency by using a measurement unit called the exchange rate (Hazizah, Viphindrartin, \& Zainuri, 2017). Then, a developing country like Indonesia with an open economy allows its citizens to have full access to the world economy. It encourages the country to make various efforts to maintain a relatively stable position of its currency exchange rate by regulating the exchange rate system adopted.

Statistics Indonesia (Badan Pusat Statistik, 2019) show that the Rupiah exchange rate fluctuates every year (see Figure 1). The average exchange 


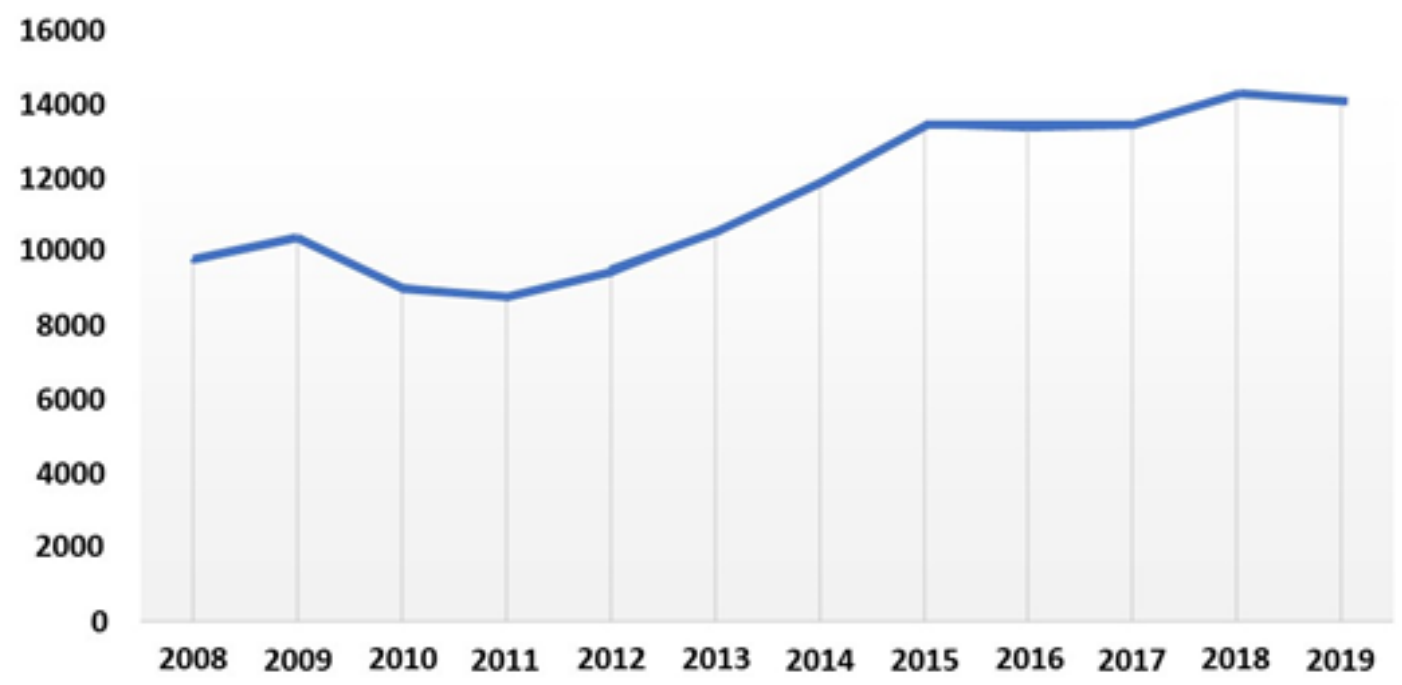

Figure 1 The Rupiah Exchange Rate against the US Dollar in 2008-2019 (in Rupiah) (Source: Badan Pusat Statistik, 2019)

rate from 2008 to 2019 was Rp12.000 per US dollar. However, the Rupiah exchange rate against the US dollar declined due to the US economic crisis in 2008 when the global financial crisis occurred. It also affected other countries throughout the world, including Indonesia. Therefore, on July 1st, 2015, Bank Indonesia issued Bank Indonesia Regulation (Peraturan Bank Indonesia - PBI) No. 17/3/2015 regarding the mandatory of using Rupiah in every transaction in Indonesia (Indonesia Investments, 2015). It is also mentioned in the article of 23 paragraph (1) of Law Number 7 of 2011 on the currency, stating the Rupiah as a means of payment or settlement of obligation in domestic financial transactions. Nevertheless, the provisions in the law still allow exceptions to its use. Using Rupiah in every purchase is considered the key to supporting the achievement of the stability of the Rupiah exchange rate.

According to Maurya (2017), the exchange rate has become the most vital determinant in a country's relative economic health. A stable exchange rate is generally seen as an indicator of sound economic management. The Rupiah exchange rate movements, weakening or strengthening, are not only influenced by government policy through the issuance of Bank Indonesia Regulations. Bank Indonesia has the primary duty to maintain the stability of the Rupiah value, which is reflected in the balance of price and exchange rate.

The exchange rate is the number of domestic currency units for one unit of foreign currency. The central bank intervenes in the foreign exchange market. Then, it sends out powerful signals to the market participants, which influence the volatility of the exchange rate movement. Factors that affect the exchange rate movements are fundamental factors, including economic indicators, such as inflation, interest rates, relative differences in income between countries, market expectation, and intervention by the central bank (Trivedi \& Apte, 2016).

According to Musyaffa and Sulasmiyati (2017), the exchange rate is an indicator that indicates the economy of a country, whether it is better than other countries or not. The higher the exchange rate of a currency to another country is, the better a country's economy than other countries will be. The literature study shows that factors affecting the exchange rate of the Rupiah against the US dollar include inflation (Arifin \& Mayasya, 2018), money supply (Muchlas \& Alamsyah, 2015), and import and interest rate (Anggraeni \& Suyahya, 2017). Based on Ali and Anwar (2011), the exchange rate changes affect the interest rate, which affects the aggregate demand for goods and services through changes in the real interest rate. On the supply side, the exchange rate depreciation negatively affects domestic companies by adjusting their prices to changes in foreign companies' valid prices.

The enactment of PBI No. 17/3/2015 has an impact on the business world. The companies accustomed to using foreign currencies in trade transactions have to be full of deceptions to continue transactions without violating policies issued by the government and maintain good relations with their partners. The cooperation agreement must be adjusted to PBI. According to Budiastawa, Santiyasa, and Pramartha (2019), the phenomenon of uncertain fluctuation of the Rupiah exchange rate that often occurs in Indonesia will cause economic conditions to be disrupted, especially trade. It is because the 
trade is valued in the US dollar. Therefore, serious arrangements are needed to face the uncertain fluctuation of the exchange rate. It will affect the economic performance of a country so that decisions can be made in the future.

Based on the phenomenon and the problem statement, the factors that affect the Rupiah exchange rate against the US dollar are formulated. It includes inflation, money supply, interest rate, and exportimport. Then, the research adds the implementation of PBI No. 17/3/2015 regarding the mandatory use of Rupiah in Indonesia's territory. The research assesses the effectiveness of government policies through PBI on the Rupiah exchange rate movements to obtain a strategy to strengthen the Rupiah exchange rate. The research will analyze the factors that influence the Rupiah exchange rate movements against the US dollar, the effect of PBI No. 17/3/2015 on the Rupiah exchange rate movements, and the behavior of Rupiah exchange rate against shocks on the variables that affect it.

The research tests the hypotheses based on the background and problems. The research also uses the PBI and the global crisis as the variables to determine their effects on the Rupiah exchange rate against the US dollar. There are six hypotheses as follows.

H1: Inflation (INF) has a significant and positive effect on the exchange rate (KURS).

H2: Money supply (M1) has a significant and negative effect on the exchange rate (KURS).

H3: Interest Rate of Bank Indonesia (SBI) has a significant and positive effect on the exchange rate (KURS).

H4: Export-import (EXIM) has a significant and negative effect on the Rupiah exchange rate (KURS).

H5: PBI No. $17 / 3 / 2015$ has a significant and negative effect on the Rupiah exchange rate (KURS).

H6: The global crisis has a significant and positive effect on the exchange rate (KURS).

\section{METHODS}

The explanatory research applies a quantitative approach. The research uses secondary data: monthly data from January 2008 to April 2019. The data are obtained from various reliable sources, namely the National Development Planning Agency (Bappenas), Bank Indonesia (BI), and Statistics Indonesia (BPS). The selected variables are based on the results of the previous research. The operational variables of the research are presented in Table 1.

The used methods in the research are descriptive analysis and Vector Error Correction Method (VECM). VECM is used because the research data are time series and to analyze long and short-term impacts. Moreover, the data are not stationary in raw form. All the data are stationary in the first difference. The equations in the model are as follows.

$$
\begin{aligned}
& D L n K U R S_{t}=a_{0}+a_{1} \operatorname{DLnKURS}_{t-1}+a_{2} \text { DLnKURS }_{t-2}
\end{aligned}
$$

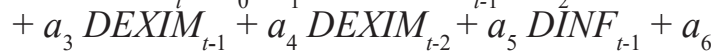

$$
\begin{aligned}
& \mathrm{DINF}_{\mathrm{t}-2}+a_{7} \mathrm{DLnM}_{\mathrm{t}-1}+a_{8} \mathrm{DLnM}_{\mathrm{t}-2}+a_{9} D S B I_{t-1} \\
& +a_{10} D S B I_{t-2}^{\mathrm{t}-2}+a_{11} E C T_{t-1}^{\mathrm{t}-1}+\varepsilon_{t}
\end{aligned}
$$$$
D L n M 1_{t}=b_{0}+b_{1} D \operatorname{LnKURS} S_{t-1}+b_{2} D L n K U R S_{t-2}
$$$$
+b_{3} \text { DEXIM }_{t-1}+b_{4} \text { DEXIM }_{t-2}+b_{5} D^{2} I N F_{t-1}+b
$$$$
D I N F_{t-2}+b_{7}{ }^{t-1} \operatorname{DnM} 1_{t-1}+b_{8}{ }^{t-2} \operatorname{DLnM} 1_{t-2}+b_{9}^{t-1} D S B I^{6}
$$$$
+b_{10} \stackrel{t-2}{D S B I_{t-2}}+b_{11} E \stackrel{t-1}{C} T_{t-1}+\varepsilon_{t}
$$$$
D I N F_{t}=c_{0}+c_{1} D \operatorname{LnKURS} S_{t-1}+c_{2} D \operatorname{LnKURS} S_{t-2}
$$$$
+c_{3} \text { DEXIM }_{t-1}+c_{4} \text { DEXIM }_{t-2}+c_{-} 5 \text { DINF }_{t-1}+
$$$$
c_{6} D I N F_{t-2}+c_{-} 7 D L n M 1_{t-1}+c_{8} D L n M 1_{t-2}+c_{9}
$$$$
D S B I_{t-1}+c_{10} \overline{D S B I} I_{t-2}+c_{11}^{t-1} E C T_{t-1}^{8}+\varepsilon_{t}
$$$$
\text { DEXIM }_{t}=d_{0}+d_{1} \text { DLnKURS }_{t-1}+d_{2} \text { DLnKURS }_{t-2}
$$$$
+d_{3} D E X I M_{t-1}+d_{4} D E X I M_{t-2}+d_{5} D_{I N F_{t-1}}+d_{6}^{t-2}
$$$$
D I N F_{t-2}+d_{7} D L n M 1_{t-1}^{t-1}+d_{8} D L n M 1_{t-2}+d_{9}^{t-1} D S B I_{t-1}^{6}
$$$$
+d_{10} \stackrel{t-2}{D S B I_{t-2}}+d_{11} E C T_{t-1}+\varepsilon_{t}
$$$$
D S B I=e_{0}+e_{1} D L n K U R S_{t-1}+e_{2} D L n K U R S_{t-2}+e_{3}
$$$$
D_{\text {EXIM }}+e_{t-1} \text { DEXIM }_{t-2}+e_{5} D_{I N F_{t-1}}+e_{6} \text { DINF }_{t-2}
$$$$
+e_{7} D L n M 1_{t-1}+e_{8} D L n M 1_{t-2}+e_{9}^{t-1} D S B I_{t-1}+e_{10}^{t-2}
$$$$
D S B I_{t-2}+e_{11} E C T_{t-1}+\varepsilon_{t}
$$

Table 1 Dependent and Independent Variables

\begin{tabular}{|c|c|c|}
\hline Ratio & Definition & Source \\
\hline $\begin{array}{l}\text { Exchange } \\
\text { rate } \\
\text { (KURS) }\end{array}$ & $\begin{array}{l}\text { The relative value of a } \\
\text { currency to the currency } \\
\text { from other countries. In } \\
\text { this case, the amount of } \\
\text { Rupiah against the US } \\
\text { dollar. }\end{array}$ & $\begin{array}{l}\text { Gitman and Zutter } \\
\text { (2012) }\end{array}$ \\
\hline $\begin{array}{l}\text { Inflation } \\
\text { (INF) }\end{array}$ & $\begin{array}{l}\text { The process of increasing } \\
\text { prices in general and } \\
\text { continuously related to } \\
\text { market mechanisms }\end{array}$ & $\begin{array}{l}\text { Arifin and Mayasya } \\
(2018)\end{array}$ \\
\hline $\begin{array}{l}\text { Money } \\
\text { supply } \\
\text { (M1) }\end{array}$ & $\begin{array}{l}\text { The banknotes held by } \\
\text { the public and the demand } \\
\text { deposits denominated in } \\
\text { Rupiah }\end{array}$ & $\begin{array}{l}\text { Muchlas and } \\
\text { Alamsyah (2015) }\end{array}$ \\
\hline $\begin{array}{l}\text { Interest } \\
\text { rate }(\mathrm{SBI})\end{array}$ & $\begin{array}{l}\text { Value, level, price, or } \\
\text { profit given to investors } \\
\text { from investment funds } \\
\text { based on calculating } \\
\text { Indonesia's economic } \\
\text { value within a specified } \\
\text { period }\end{array}$ & $\begin{array}{l}\text { Musyaffa and } \\
\text { Sulasmiyati (2017) }\end{array}$ \\
\hline $\begin{array}{l}\text { Export- } \\
\text { import } \\
\text { (EXIM) }\end{array}$ & $\begin{array}{l}\text { The ratio between the } \\
\text { values of export and } \\
\text { import }\end{array}$ & Hazizah et al. (2017) \\
\hline PBI & $\begin{array}{l}\text { Policy dummy: } \\
0=\text { before the policy on } \\
\text { the mandatory to use } \\
\text { Rupiah in } 2008-2015 \\
1=\text { after the policy on the } \\
\text { mandatory to use Rupiah } \\
\text { in 2016-2019 }\end{array}$ & \\
\hline $\begin{array}{l}\text { Global } \\
\text { crisis }\end{array}$ & $\begin{array}{l}0=\text { No crisis }(2009-2019) \\
1=\text { Crisis }(2008)\end{array}$ & \\
\hline
\end{tabular}
in the Research 
Before the VECM test, the preliminary tests have to be done first. The initial test is stationarity, Granger causality, lag length determination, cointegration, and Vector Autoregression (VAR) stability test. The stationarity test on data in each dependent and independent variable is conducted to obtain the VECM estimation. The Granger causality test determines each variable's causal relationship. It also proves a two-way relationship between variables, which shows that all variables in the VAR/VECM model are endogenous variables. Then, the test level in the granger causality test is the significance level of $0,05(5 \%)$, and the lag length is up to lag 2 according to the optimum lag length test that has been conducted (Khin et al., 2017).

After that, the lag length is determined based on the highest value in the sequential modified Long Run (LR) test statistic. The lag length of the research is from zero to two. The data are monthly data from January 2008 to April 2019. The next step in the VECM estimation is the cointegration test. It aims to determine the long-term relationship in each variable. The VECM estimation requires a cointegration relationship. If there is no cointegration relationship, the VECM estimation cannot be used. It must use the VAR model. Johansen's cointegration test method is available in Eviews 9 software with a critical value of 0,05 . Meanwhile, the stability test of VAR model estimation checks the condition of VAR stability in the form of the polynomial roots. A VAR system is stable if the modulus value result is less than one (Khin, Yee, Seng, Wan, \& Xian, 2017).

The impulse response test analyzes the dynamic structure of the variables in the observed model, as reflected by the innovation variables. This test consists of the Impulse Response Function (IRF) and the Cholesky decomposition (the variance decomposition). The IRF is used to see how an endogenous variable responds to specific variables (Parot, Michell, \& Kristjanpoller, 2019). The Cholesky decomposition, commonly called Forecast Error Variance Decomposition (FEVD), provides information about innovation variables that are relatively more important in VAR and the dynamic relationship between the analyzed variables. Besides, the FEVD results can indicate how significant the effect of random shocks of certain variables on endogenous variables (Sulistiana, Hidayati, \& Sumar, 2017).

\section{RESULTS AND DISCUSSIONS}

The Rupiah exchange rate movements against the US dollar from January 2008 to April 2019 showed relatively high fluctuation in 2008 (see Figure 2). It was due to the global crisis. The orange line indicated the limit of PBI No. 17/3/2015 regarding the usage of Rupiah in each transaction in April 2015. The Rupiah exchange rate movements continued to increase after enacting PBI No. 17/3/2015 in April 2015.

Table 2 shows the average value of the total exchange rate of $11.383,60$. The average Rupiah exchange rate is set at $10.077,16$ before and $13.703,18$ after the enactment of PBI No. 17/3/2015. The results indicate that the average value of the Rupiah exchange rate after the PBI is higher than before the PBI.

Then, the research analyzes the effects of inflation, export-import, interest rate of Bank Indonesia, money supply, implementation of PBI, and global crisis on the Rupiah Exchange Rate. The stationarity test or unit root test aims to verify whether the studied data are stationary based on the probability value. If the probability value is higher than $5 \%$, it means the data is not stationary. Conversely, if the probability is lower than the level, the data is stationary. According to the Augmented Dickey-Fuller (ADF) stationarity test results, only the money supply meets the stationarity requirements level.

The results of the stationary test show that none of the variables meet the stationary requirements at the level, except for the money supply. The money supply in ADF test results at the level of the probability value $(0,038)$ is smaller than the alpha of $5 \%$. It means that it is stationary at the level. However, the exchange rate in the ADF test produces a probability value of 0,665 (greater than alpha of $5 \%$ ), so it is not stationary at the level. Similarly, export-import, inflation, and interest rate of Bank Indonesia have probability values of $0,193,0,113$, and 0,085 , respectively. The overall value is greater than the alpha of 5\% (not stationary at the level). Meanwhile, the results of the ADF test on the first difference obtain a probability value of 0,000 , smaller than alpha $5 \%$. Hence, the exchange rate is stationary in the first difference.

Next, the Granger causality test determines the causal relationship of each variable. The test shows a two-way relationship between variables. It also indicates that all variables in the VAR or VECM

Table 2 Descriptive Analysis of Rupiah Exchange Rate

\begin{tabular}{lccccc}
\hline Data & N & Min. & Max. & Mean & Standard Deviation \\
\hline Total & 136 & 8.508 & 15.227 & $11.383,60$ & $2.042,40$ \\
Before PBI & 87 & 8.508 & 13.084 & $10.077,16$ & $1.264,43$ \\
After PBI & 49 & 12.937 & 15.227 & $13.703,18$ & 530,50 \\
\hline
\end{tabular}

(Source: Data processing with SPSS, 2019) 


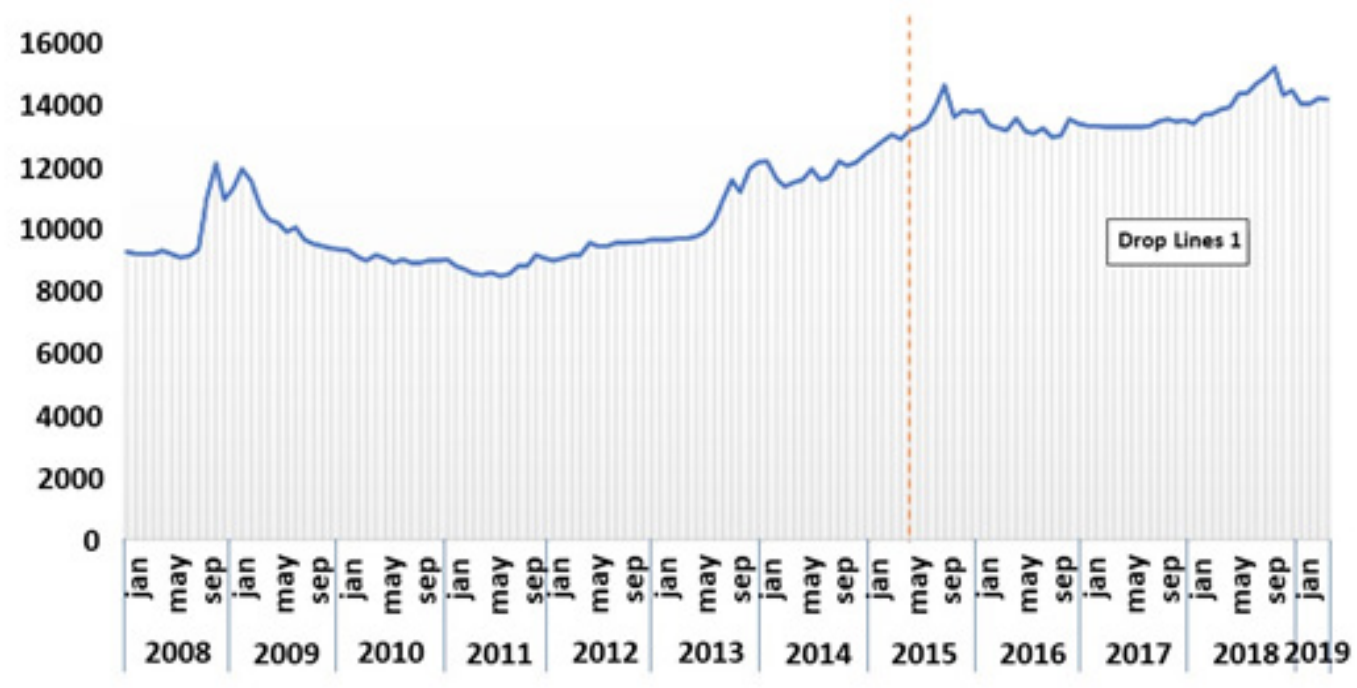

Figure 2 The Rupiah Exchange Rate Movements against the US Dollar in 2008-2019

(Source: Statistics Indonesia, 2019)

model are endogenous variables. The used level test in the Granger causality test is the significance level of $0,05(5 \%)$, and the lag length is up to lag 2 according to the conducted optimum lag length test. Based on the causality test results, there is a significant causal relationship (two directions) between the variables of export-import and the exchange rate.

Similarly, the causal relationship between inflation and exchange rate also indicates a two-way relationship or a significant cause. At the same time, the causal relationship between the money supply and interest rate of Bank Indonesia on the exchange rate has been proven significantly. Causality test results between the money supply and inflation show a higher probability value than alpha $5 \%$. There is no two-way or causal relationship between the money supply and inflation. The result is similar to the money supply and interest rate of Bank Indonesia. It shows a higher probability value than the alpha of $5 \%$. So, there is no two-way or causal relationship between the money supply and the interest rate of Bank Indonesia.

The next test is lag length determination. VECM estimation is sensitive to the lag length of the data. The lag length determination is conducted based on the highest value of the sequential modified LR test statistic. The lag length in the research is lags 0 to 2 because the data are monthly data and 12 years only. The lag length is sufficient to illustrate the global capital market's cointegration to Indonesia's capital market in the monthly period of January 2008 to April 2019. The optimal lag length is lag 3, with the highest value of sequential modified the Akaike Information Criterion (AIC) test statistic of $-12,70749$. Therefore, the optimal lag in the research is lag 3.

The further stage in VECM estimation is the cointegration test. Cointegration test results show three cointegrating ranks of the variables on the test level of $5 \%(0,05)$. It proves that the trace statistic values of 171,5451 and 98,4513 are higher than the critical values of 0,05 , i.e., 95,7537 and 69,8189 (the result from the cointegration test can be seen in Appendix). It means $\mathrm{HO}$ is rejected, and $\mathrm{H} 1$ is accepted. In other words, the variables have a long-term relationship (cointegration) with one another. Therefore, the VECM estimation is used, and the VECM stability test is conducted in the next stage.

In the VECM stability test, the stability test is to see the validity of IRF and Variance Decomposition (VDC). The model shows stable results because the modulus value is less than 1 . The modulus range indicates the average value of less than one. Thus, the analysis of IRF and VDC is valid.

Moreover, the research interprets the result of VECM estimation results. It is the long-term effect on the exchange rate. The VECM estimation identifies the short and long-term relationships of the effect of the independent variable on the dependent variable. The VECM estimation results for the long-term equation are shown in Table 3. Factors affecting the exchange rate in the long term are shown in the equation as follows.

$\mathrm{Y}=16,7885-1,8389 \mathrm{X}_{1}-0,0043 \mathrm{X}_{2}-0,5473 \mathrm{X}_{3}+$ $0,3982 \mathrm{X}_{4}$

Details:

Y : Ln_exchange rate

$\mathrm{X}_{1}$ : Inflation

$\mathrm{X}_{2}$ : Export-import

$\mathrm{X}_{3}$ : Ln_money supply

$\mathrm{X}_{4}$ : Interest rate of Bank Indonesia 
Table 3 Long-Term Equation

\begin{tabular}{lll}
\hline $\begin{array}{l}\text { Cointegrating Eq: } \\
\text { LN_exchange rate (-1) }\end{array}$ & & CointEq1 \\
\hline EXIM (-1) & Coefficient & $\mathbf{1}$ \\
& Standard Error & 0,4327 \\
& T-count & {$[4,24961]^{* *}$} \\
INFLASI (-1) & Coefficient & $-0,0043$ \\
& Standard Error & 0,0256 \\
& T-count & {$[0,16896]$} \\
LNM1(-1) & Coefficient & $-0,5473$ \\
& Standard Error & 0,1729 \\
& T-count & {$[3,16588]^{* *}$} \\
SBI (-1) & Coefficient & 0,3982 \\
& Standard Error & 0,0632 \\
& T-count & {$[-6,30240]^{* *}$} \\
C & & 16,7885 \\
\hline
\end{tabular}

Note: **) t-count $>$ t-table (significant)

The long and short-term equation results of the effects on exchange rate indicate the export-import has a significant negative impact on the exchange rate. The hypothesis is accepted. The absolute value of t-count is 4,24961 (see Table 3). It is higher than the $\mathrm{t}$-table of 1,96 . The coefficient of $-1,8389$ shows that a $1 \%$ increase in the export-import will weaken or strengthen the Rupiah exchange rate by $1,8389 \%$ by using ceteris paribus in the assumption.

According to Silitonga, Ishak, and Mukhlis (2017), net exports are factors that can encourage a country's currency exchange rate to rise and fall. The stability of the Rupiah exchange rate becomes an important issue for business sectors closely related to export-import activities. The businesses with raw materials depend on imports and the weakening of the Rupiah against foreign currencies, especially the US dollar. Those factors will impact rising production costs. However, on the other hand, for the businesses that set exports as their core business, the weakening of the Rupiah against foreign currencies, especially the US dollar, can provide additional benefits over exchange rate differences.

The export-based sector is expected to become a mainstay for Indonesia's business sector by paying attention to exported business products (finished goods and semi-finished goods) to provide more added value to the product. The stability of exchange rate movements must be maintained. If the strength of the Rupiah is too high against the US dollar, it will impact many export-import agreements and affect the profits of the business sector due to changes in exchange rate differences. A large foreign exchange reserve is needed to keep the Rupiah's relatively stable movement against the US dollar. A large foreign exchange reserve is generated when export activity has increased. Thus, the ratio of exports to imports can significantly and negatively affect the exchange rate when the ratio of imports is higher than exports.

According to Sabtiadi and Kartikasari (2018), there is a negative and significant effect between the national export on the US dollar exchange rate. The gain in exports will increase the demand for domestic currency and strengthen Rupiah. Moreover, the high amount of export decreases unemployment and increases the per capita income of a state so that purchasing power is boosted. Meanwhile, massive import weakens the domestic currency since it increases the demand for foreign currencies. It reduces domestic production, increases unemployment, and lowers income. As a result, the public's purchasing power will also decrease. Therefore, to maintain stability and increase the trend of the Rupiah exchange rate, it is not sufficient to solely require the domestic businesses to transact using the Rupiah. The high amount of exports will also have an impact on increasing employment. It can reduce unemployment and increase the purchasing power of the public. The increase in purchasing power will boost domestic consumption. It is an opportunity for the business sector. One of the efforts to reduce dependence on imports of raw materials is to build a supply chain and database of superior products in the country to find centers of domestic raw materials with competitive prices.

A country will get the value of a certain amount of money in foreign currency or foreign exchange in export activities, which is one of the sources of state income. The entry of foreign currency payments will increase the demand for Rupiah because of the need to exchange foreign currencies for local currency. The increasing demand for Rupiah will increase the exchange rate. Therefore, gradually but surely, the business actors can reduce their dependence on imports, especially raw material procurement. If the imported raw materials are cheaper than domestic raw materials, the business actors need to produce products in the form of finished or semi-finished goods. So, they can be exported and provide added value. For instance, in the mining industry, the government has obliged mining businesses to build smelters domestically to export mining products in finished goods.

Then, when large corporations can cooperate with Micro, Small \& Medium Enterprises (MSMEs) as their business partners, they will have market certainty to absorb the produced products. The supply chain built by large corporations is a large market circle for MSMEs. The empowerment of the MSME sector cooperated with large corporations will impact the welfare of the workers and create new jobs. At this point, the public's purchasing power will increase and raise the demand for the Rupiah. If this policy is implemented, prosperity will occur domestically, and Indonesia can gradually reduce its dependence on imports and prioritize exports to keep increasing. Large imports will increase the demand for foreign currencies so that the domestic currency weakens. Large imports will also reduce domestic production due to rising unemployment and declining income. Then, it will also decrease the purchasing power. It 
gives an illustration particularly to the government on how to keep increasing Indonesia's exports to preserve the stability of the Rupiah exchange rate against the US dollar.

Moreover, inflation has no significant effect on the exchange rate in the long and short term. The hypothesis is rejected. The absolute value of t-count of 0,16896 (see Table 3 ) is lower than the t-table of 1,96. It illustrates the increase in the price of available goods in public. The price level affects the number of offers and the money supply. The rising costs of goods encourage inflation. This inflation will make the Rupiah depreciate as the public's purchasing power decreases on an item. The same amount of money from last year cannot afford the same item in this year. As of this writing, inflation does not affect the exchange rate. The rise or fall of the Rupiah against the US dollar does not affect the public's purchasing power. The result is in line with Firmansyah and Nuzula (2017). The inflation is not significant to the exchange rate.

Next, the money supply has a significant and negative effect on the Rupiah exchange rate movements in the long and short term. The hypothesis is accepted. The absolute value of the t-count of 3,16588 is higher than the t-table of 1,96. The result follows Suidarma, Sanica, Ayu, and Darma (2018). In the long term, money supply or monetary aggregate has negative relation to exchange rate movement in which the increase of money supply or monetary aggregate causes exchange rate depreciation.

According to Musyaffa and Sulasmiyati (2017), the money supply is one of the macroeconomic factors that are based on the concept development of money quantity theory in the monetary approach. The money supply holds an essential role in the economy of a country. The excessive money supply in the economy will put pressure on the currency exchange rate against foreign currencies. The rising money supply increases the price of goods measured by money and foreign currencies measured by domestic currency.

The money supply is money held by the public. The money supply is the sum of all banknotes held by the public (the non-public bank) and demand deposits owned by individuals in commercial banks (Sukirno, 2001). Based on Muchlas and Alamsyah (2015), the money supply impacts the Rupiah exchange rate movements against the US dollar. If the supply of Rupiah increases, the value will be depreciated.

According to Miskhin (2011), an increase in the money supply will lead to a higher US dollar price level and reduce the future exchange rate. The money supply changes encourage the exchange rate to overshoot and cause the exchange rate to hugely change in the short run rather than the long run. The higher domestic money supply will cause the local currency to depreciate. If there is too much money in circulation, the public will use it more for the transaction process. Then, it leads to an increase in the prices of the goods in the country.

Partially both in the short and long terms, the length of each variable's behavior has a fluctuating effect. The money supply difference in a broad sense between Indonesia and the United States positively affects a significant change in the Rupiah exchange rate against the US dollar. It means that every increase in domestic money will depreciate, or the Rupiah supply rises. Hence, the amount of money supply relatively influences the Rupiah exchange rate. A currency will decrease in its value if the money supply is issued more (Hazizah et al., 2017).

Next, the interest rate of Bank Indonesia has a significant and positive effect on the exchange rate in the long and short term. The hypothesis is accepted. The absolute value of $t$-count of $-6,30240$ (see Table 3) is higher than the t-table of 1,96. The significant and positive effect of the interest rate of Bank Indonesia on the exchange rate simultaneously indicates that its changes also influence the Rupiah exchange rate movements against foreign currencies in the same direction. The gain of interest rate will increase the exchange rate. It is due to the interest rate that has grown. It means that saving in Rupiah will provide a high reward because it will lead to Indonesia's capital inflows. It will boost the price of the Rupiah against the US dollar.

Under normal circumstances, investors will expect a high return on investment instruments they choose, including currencies. Interest rate, in this case, significantly affects the exchange rate of one currency against other currencies. The interest rate determines the value-added of a currency. The higher the interest rate of a currency is, the higher the demand for that country's currency will be. The increase in the interest rate in a country can encourage the transfer of funds or financial instruments from currencies with low interest rates to currencies with higher interest rates. A decrease in the domestic interest rate causes depreciation or weakening of the local currency exchange rate. However, an increase in domestic interest rates causes appreciation or strengthening of the internal currency exchange rate (Tho' in \& Prastiwi, 2019).

According to Krušković (2017), an increase in the domestic interest rate related to the foreign interest rate leads to foreign capital inflows. Then, it results in the exchange rate appreciation. Contrary to that statement, an increase in domestic prices related to foreign prices leads to altered demand in favor of foreign goods and results in exchange rate depreciation. High volatility of foreign exchange reserves can cause instability of the exchange rate. Monetary authorities discontinue the inflationary impact of foreign exchange inflows by accumulating foreign exchange reserves and reducing their money supply effects.

Moreover, the central bank should intervene to reduce inflationary pressures and appreciation of the real exchange rate and avoid losing control over the domestic money supply. However, the increase in the interest rate of Bank Indonesia, which is usually accompanied by an increase in the deposit rate, will slow investment in the country's real business sector. People who have excess liquidity are reluctant to invest their funds in the real sectors and prefer to save 
their bank funds because of the lower risk level. It will affect the movement of the real sector.

Furthermore, the enaction of PBI No. 17/3/2015 on the usage of Rupiah as a derivative regulation of Act Number 7 of 2011 on the currency has a positive and significant effect in the long and short term. The hypothesis is rejected). This condition shows that the implementation of the regulation generates an average increase in the Rupiah exchange rate against foreign currencies, specifically to the US dollar. Therefore, the application of PBI No. 17/3/2015 is not effective.

The average changes in the exchange rate after the policy on using the Rupiah is higher than the average changes in the exchange rate before it. Therefore, PBI No. 17/3/2015 on the mandatory use of Rupiah as a derivative of law No. 7/2011 on currency, as written in Article 23 paragraph (1). It stipulates that Rupiah as a means of payment or settlement of obligation in domestic financial transactions is ineffective. PBI took effect by June $1^{\text {st }}, 2015$. Hence, there was an adjustment or transition period for noncash transactions until June 30th, 2015. The transition period intends to finalize the agreements for the companies in using foreign exchanges. Through this PBI, Rupiah can become a symbol of Indonesia's sovereignty and control the exchange rate due to soaring foreign exchange demand.

The implementation of transactions using Rupiah in Indonesia is regulated, but law enforcement is still relatively weak. The technical regulation issued in the form of PBI. However, there are many criticisms that the regulation seems softer than the law. Moreover, limiting transactions using the dollar is not simple. Even though it is implemented domestically, it is relatively difficult considering the intensive traffic of goods, capital, and investment across the countries. Many businesses apply dollar prices in domestic transactions because they have to make purchases in foreign currency. The results illustrate that to control the Rupiah exchange rate movements, it cannot be implemented only by using a regulation that requires the usage of Rupiah. However, it also needs to be supported by other concrete steps from the business world.

The global crisis is not significant to the changes in exchange rates. The hypothesis is rejected. The exchange rate is the primary consideration for most central banks in determining monetary policy. A strong domestic currency puts a drag on the economy and achieves the same results with tighter monetary policy, namely the higher interest rate. Besides, further tightening of monetary policy when the domestic currency is too strong can exacerbate the problem, such as attracting more hot money from foreign investors who look for investments with higher yields that will push the domestic currency.

Based on the research results, the current weakening of the Rupiah occurs due to complex factors that are mostly coming from the external side. However, the role of the domestic foreign exchange market also contributes to this issue. If the dollar demand continues to increase for abroad and domestic transactions while the supply does not increase, it will make the exchange rate plummets. Therefore, the need to limit dollar transactions in the country and intensify other rules can hamper dollar demand. The government can coordinate with major players, especially State-Owned Enterprises (SOEs), with large transactional needs in dollar. For example, PT Pertamina no longer seeks dollar in the market when it needs them. It buys dollar in Bank Indonesia. Other actors also need to identify to fine-tune (regulate) dollar needs. Then, the government can intensify the hedging mechanism for as many businesses as possible with dollar transactions. Thus, the demand for dollar is slightly controlled dynamically. Besides the demand factor, the supply side must be improved. The high dollar demand when the supply is limited will make the Rupiah fall. The regulation of export proceeds (Devisa Hasil Expor - DHE) needs to be re-intensified. In some other central banks of other countries, the division that handles DHE is still quite large.

Then, IRF analysis explains the impact of shocks in one variable on other variables in the short and long run. The result of IRF analysis of exchange rate due to other variables that are given shock is in Figure 3. The IRF analysis also sees how long the influence lasts. The data use monthly data from January 2008 to April 2019. A long period describes the response of the dependent variable to the independent variable. First, the impulse results of export-import in the exchange rate response by 50 periods in the future show a positive response $(+)$ to the exchange rate. The response takes place throughout the period, from the first period to the tenth period. Second, the exchange rate response to shocks from inflation lasts from the first to the fifth period. Third, the exchange rate response to shock from the money supply is positive $(+)$. The shock from the money supply lasts from the fifth to the sixth period. Fourth, the exchange rate response to shock from the interest rate of Bank Indonesia is positive $(+)$. The shock lasts from the first to the fifth period. In conclusion, the shock of the export-import has the longest response by the exchange rate.
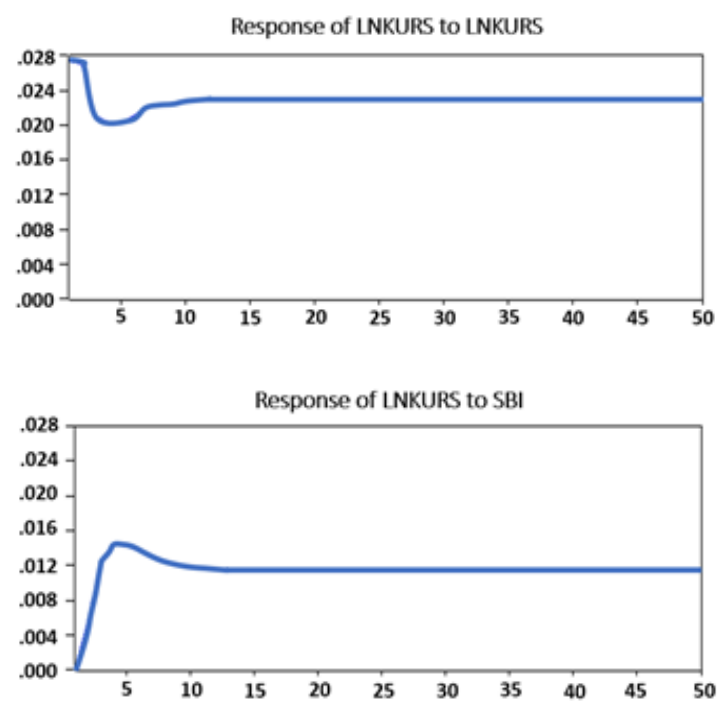

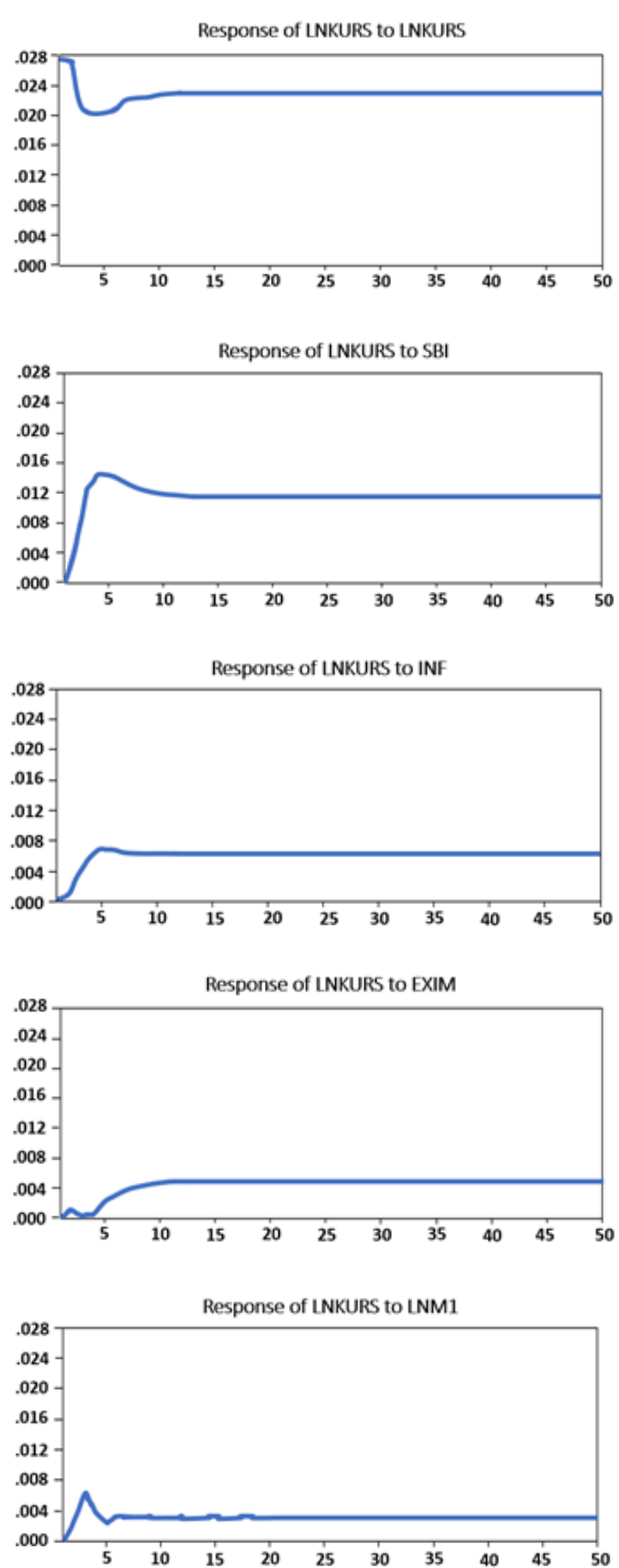

Figure 3 The IRF Analysis Results of Exchange Rate Response due to Other Variables That are Given Shock

Moreover, the dynamic structure between variables in VAR is identified through FEVD analysis. The pattern of FEVD indicates the nature of multivariate causality among the variables in the VAR model. The order of the variables in the FEVD analysis is based on the Cholesky factorization. The following are the results of variance decomposition up to 50 periods in the future. FEVD of the exchange rate is shown in Figure 4.

The exchange rate shock itself causes the first period of exchange rate fluctuations by $100 \%$. Since the fifth period, the exchange rate begins to decline, and roles of other variables are seen. During this period, the exchange rate still dominates by $80 \%$. The variable that has the most important role in exchange rate fluctuations is the interest rate of Bank Indonesia, around $18 \%$. The second is inflation by $4 \%$, followed by the export-import by $3 \%$ and money supply by $1,27 \%$. In the tenth period, there is a decline in the exchange rate by almost $10 \%$. Furthermore, the percentage of exchange rate tends to be stable until the fiftieth period.

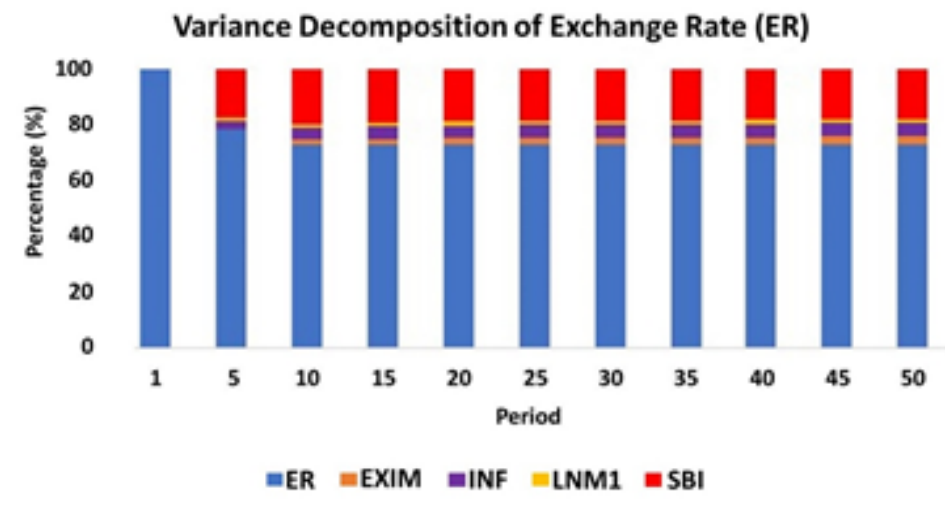

Figure 4 Variance Decomposition of the Exchange Rate

\section{CONCLUSIONS}

Based on the results, there are several conclusions. The VECM results show that the factors that influence the Rupiah exchange rate movements against the US dollar are the money supply and the interest rate of Bank Indonesia. Meanwhile, the exportimport, inflation, and global crisis do not significantly influence the Rupiah exchange rate.

Then, PBI No. 17/3/2015 has a significant and positive effect on the Rupiah exchange rate. The implementation of the PBI No. 17/3/2015 produces the average Rupiah exchange rate that is higher than the US dollar compared to before it is implemented. However, the obligations of domestic financial transactions are not effective in controlling the stability of the Rupiah exchange rate movements against the US dollar.

The IRF results show that the shocks of exportimport, inflation, money supply, and interest rate have positive effects on the movement of the Rupiah exchange rate. Thus, if a shock occurs, it will cause a depreciation of the Rupiah against the US dollar. Based on the FEVD analysis, the variables that have the most important role in the exchange rate fluctuations are the interest rate of Bank Indonesia, inflation, exportimport, and money supply.

Two strategies can be done by the government. First, it should coordinate with large companies with large dollar transaction needs, especially State-Owned Enterprises (SOEs). Second, the government must also intensify the hedging mechanism for as many businesses as possible with US dollar transactions. 
Retrieval data in future research is recommended by using the same variable but using annual data after the enactment of PBI No. 17/3/2015. Future research is expected to use different methods and add macroeconomic variables to enrich studies related to the Rupiah exchange rate against the US dollar. Moreover, the research only discusses the policies and indicators of macroeconomics. Hence, a deeper discussion on global conditions qualitatively should be conducted through interviews with experts in further research.

\section{REFERENCES}

Ali, S. Z., \& Anwar, S. (2011). Supply-side effects of exchange rates, exchange rate expectations and induced currency depreciation. Economic Modelling, 28(4), 1650-1672.

Anggraeni, W., \& Suyahya, I. (2017). Pengaruh antara tingkat suku bunga, tingkat inflasi, dan jumlah barang impor dengan nilai tukar rupiah terhadap Dolar Amerika. JABE (Journal of Applied Business and Economic), 3(2), 81-89.

Arifin, S., \& Mayasya, S. (2018). Faktor-faktor yang mempengaruhi nilai tukar Rupiah terhadap Dolar Amerika Serikat. Jurnal Ekonomi-Qu (Jurnal Ilmu Ekonomi), 8(1), 82-96.

Badan Pusat Statistik. (2019). Kurs tengah beberapa mata uang asing terhadap Rupiah di Bank Indonesia dan harga emas di Jakarta (Rupiah), 2000-2019. Retrieved from https://www.bps.go.id/ linkTableDinamis/view/id/952

Budiastawa, I. D. G., Santiyasa, I., \& Pramartha, C. R. A. (2019). Prediksi dan akurasi nilai tukar mata uang Rupiah terhadap US Dolar menggunakan radial basis function neural network. Jurnal Elektronik Ilmu Komputer Udayana, 7(4), 309-317.

Firmansyah, M. W., \& Nuzula, N. F. (2017). Pengaruh rasio inflasi dan suku bunga Indonesia relatif terhadap Amerika Serikat pada nilai tukar Rupiah (Implementasi purchasing power parity internasional fisher effect). Jurnal Administrasi Bisnis, 47(2), 5764.

Gitman, L. J., \& Zutter, C. J. (2012). Principles of managerial finance. Pearson.

Hazizah, N., Viphindrartin, S., \& Zainuri, Z. (2017). Pengaruh JUB, suku bunga, inflasi, ekspor dan impor terhadap nilai tukar Rupiah atas Dollar Amerika Serikat. E-Journal Ekonomi Bisnis dan Akuntansi, 4(1), 97-103.

Indonesia Investments. (2015). Peraturan Bank Indonesia 'kewajiban penggunaan Rupiah' mulai berlaku. Retrieved from https://www.indonesia-investments. com/id/berita/berita-hari-ini/peraturan-bankindonesia-kewajiban-penggunaan-rupiah-mulaiberlaku/item 5695
Khin, A. A., Yee, C. Y., Seng, L. S., Wan, C. M., \& Xian, G. Q. (2017). Exchange rate volatility on macroeconomic determinants in Malaysia: Vector Error Correction Method (VECM) model. Journal of Global Business and Social Entrepreneurship, 3(5), 36-45.

Krušković, B. D. (2017). Exchange rate and interest rate in the monetary policy reaction function. Journal of Central Banking Theory and Practice, 6(1), 55-86.

Maurya, S. (2017). Factors affecting exchange rate and its impact on economy of India. Asian Journal of Research in Business Economics and Management, 7(8), 324-347.

Miskhin, F. (2011). Ekonomi uang, perbankan, dan pasar keuangan ( $8^{\text {th }}$ ed.). Salemba Empat.

Muchlas, Z., \& Alamsyah, A. R. (2015). Faktor-faktor yang mempengaruhi kurs Rupiah terhadap Dolar Amerika pasca krisis (2000-2010). Jurnal Jibeka, 9(1), 76-86.

Musyaffa, A. S., \& Sulasmiyati, S. (2017). pengaruh jumlah uang beredar, inflasi dan suku bunga terhadap nilai tukar Rupiah terhadap Dollar (Studi pada Bank Indonesia periode 2011-2015). Jurnal Administrasi Bisnis, 50(4), 19-24.

Parot, A., Michell, K., \& Kristjanpoller, W. D. (2019). Using artificial neural networks to forecast exchange rate, including VAR-VECM residual analysis and prediction linear combination. Intelligent Systems in Accounting, Finance and Management, 26(1), 3-15.

Sabtiadi, K., \& Kartikasari, D. (2018). Analisis pengaruh ekspor impor terhadap nilai tukar USD dan SGD. Jurnal Akuntansi, Ekonomi dan Manajemen Bisnis, 6(2), 135-141.

Silitonga, R. B., Ishak, Z., \& Mukhlis, M. (2017). Pengaruh ekspor, impor, dan inflasi terhadap nilai tukar Rupiah di Indonesia. Jurnal Ekonomi Pembangunan, 15(1), 53-59.

Suidarma, I. M., Sanica, I. G., Ayu, P. C., \& Darma, I. G. N. (2018). Overshooting Indonesian Rupiah's exchange rate towards US Dollar: Dornbusch model hypotheses test. International Journal of Economics and Financial Issues, 8(5), 52-58.

Sukirno, S. (2001). Makroekonomi. Indonesia: PT Raja Grafindo.

Sulistiana, I., Hidayati, \& Sumar. (2017). Model Vector Auto Regression (VAR) and Vector Error Correction Model (VECM) approach for inflation relations analysis, Gross Regional Domestic Product (GDP), world tin price, BI rate and Rupiah exchange rate. Integrated Journal of Business and Economics, 1(2), 17-32.

Tho'in, M., \& Prastiwi, I. E. (2019). An analysis the Rupiah exchange rates effect against the American Dollar and inflation against the growth of Islamic Banking Mudharabah deposits in Indonesia. International Journal of Islamic Business and Economics (IJIBEC), 3(1), 82-91.

Trivedi, S. R., \& Apte, P. G. (2016). Central bank intervention in USD/INR market: Estimating its reaction function and impact on volatility. Asia-Pacific Financial Markets, 23(3), 263-279. 


\section{APPENDIX}

\section{Cointegration Test}

Date: 08/10/19 Time: 13:24

Sample (adjusted): 2008M02 2019M04

Included observations: 135 after adjustments

Trend assumption: Linear deterministic trend

Series: LNKURS EXIM INF LNM1 LNM2 SBI

Lags interval (in first differences): No lags

Unrestricted Cointegration Rank Test (Trace)

\begin{tabular}{cccccc}
\hline $\begin{array}{c}\text { Hypothesized } \\
\text { No. of CE(s) }\end{array}$ & Eigenvalue & $\begin{array}{c}\text { Trace } \\
\text { Statistic }\end{array}$ & $\begin{array}{c}0,05 \\
\text { Critical Value }\end{array}$ & Prob.** & Conclusion \\
\hline None* & 0,4181 & 171,5451 & 95,7537 & 0,0000 & \\
At most 1* & 0,3363 & 98,4513 & 69,8189 & 0,0001 & \\
At most 2 & 0,1195 & 43,1215 & 47,8561 & 0,1296 & Cointegrated \\
At most 3 & 0,0853 & 25,9477 & 29,7971 & 0,1303 & \\
At most 4 & 0,0683 & 13,9068 & 15,4947 & 0,0855 & \\
At most 5* & 0,0318 & 4,3589 & 3,8415 & 0,0368 & \\
\hline Trace test indicates 2 cointegrating eqn(s) at the 0,05 level & & \\
* Denotes rejection of the hypothesis at the 0,05 level & \\
**MacKinnon-Haug-Michelis (1999) p-values
\end{tabular}

